\title{
PERANAN KOMUNIKASI DENGAN STAKE HOLDER DALAM MEWUJUDKAN EFEKTIVITAS PENERAPAN HUKUM (Studi Kasus Dalam Pelaksanaan Syariat Islam di Provinsi Aceh)
}

\author{
Teuku Ahmad Yani \\ Fakultas Ilmu Sosial dan Ilmu Politik, Universitas Teuku Umar \\ Email: Teukuahmadyani@utu.ac.id
}

\begin{abstract}
The role of communication is very important for the efforts effectivity of enforcement of a law. The communication must go two ways, so that from the beginning of the stakeholders have been able to communicate the values they expect to be in their midst. The role of this communication, should be initiated in academic papers, which is a condition that must be held at all stages of the formation of law in Indonesia, including Aceh Local Law about Jinayah.
\end{abstract}

Keywords: Communication, Stakeholder, and Affectivity

\section{PENDAHULUAN}

\section{Latar Belakang dan Permasalahan}

Manusia menurut Aristoteles adalah mahkluk sosial, sehingga setiap saat manusia harus saling berhubungan satu dengan lainnya. Hubungan itu dapat terjadi skala kecil, misalnya dalam rumah tangga, ataupun dalam skala yang lebih luas, yaitu dalam tingkat desa, kecamatan, kabupaten/kota, provinsi, nasional, regional bahkan internasional.

Komunikasi itu diperlukan dalam semua aspek kehidupan masyarakat (Hafied Cangara, 1998:3), mulai dari hal-hal untuk memenuhi kebutuhan sehari-hari sampai halhal yang lebih luas dari itu, misalnya dalam persoalan di bidang hukum. Secara teoritis, Cicero seorang filsuf menyebutkan bahwa dimana ada manusia ada hukum. Oleh karena itu antara hukum dengan masyarakat tidak dapat dipisahkan satu sama lain, yaitu hukum ada karena ada masyarakat dan begitu pula sebaliknya, masyarakat selalu membutuhkan hukum untuk mengatur diri mereka.

Komunikasi dalam bidang hukum diperlukan, karena hukum diperlukan untuk manusia, dimana manusia diperlakukan sebagai subyek hukum (Soeroso, 2004: 227), bukan sebagai obyek. Obyek hukum bukanlah manusia, melainkan benda. Oleh karena itu, hukum sangat melarang manusia dijadikan sebagai obyek jual beli, misalnya.

Keperluan komunikasi dalam bidang hukum, tidak hanya pada saat penerapan, melainkan pula jauh sebelum norma hukum terbentuk, yaitu pada masa sebelum pembentukan norma-norma hukum itu. Efektifitas keberlakuan suatu norma hukum di tengah-tengah masyarakat sangat tergantung pada penerimaan norma hukum itu oleh masyarakat. Oleh karena itu, karena kurangnya berjalannya metode berkomunikasi dari segenap langkah guna menuju efektifitas pemberlakuan hukum itu, maka tidak mengherankan banyak norma-norma hukum tertentu yang ditentang keberlakuannya oleh masyarakat.

Sebagai contoh, dalam bidang penerapan syariat Islam di Aceh, terjadi beberapa polemik terhadap keberadaannya. Polemik itu tidak hanya terjadi di Aceh, melainkan di laur Aceh, baik secara nasional maupun internasional, dimana menganggap pemberlakuan syariat Islam melanggar konstitusi Indonesia, bahkan juga pelanggaran hak asasi manusia. 
Secara perlahan, penerapan syariat Islam di Aceh mulai kurang penolakan dari pihak tertentu. Sebaliknya, pemberlakuan syariat Islam di Aceh justeru mengalami berbagai kemajuan. Meskipun belum dapat dilaksanakan secara kaffah, karena hambatan dari norma hukum itu sendiri, namun aroma pengakuan dan perlunya penerapan syariat Islam terus bergerak kepada korelasi yang positip. Untuk itu dalam tulisan ini, ingin dikaji tentang perlunya komunikasi dalam mendorong berlakunya norma hukum secara efektif, khususnya norma hukum syariat Islam di Aceh.

\section{Tujuan dan Manfaat}

Tujuan dari kajian ini adalah untuk mengkaji peran komunikasi massa dalam mendorong terciptanya komunikasi yang efektif untuk dapat terimplementasi syariat Islam Islam di Aceh. Selain itu, dari segi akademis kajian ini dapat memberikan pengetahuan dan pemahaman tentang pentingnya komunikasi massa dalam menciptakan pelaksanaan norma-norama tentang syariat islam di Aceh.

\section{METODE PENELITIAN}

Untuk mengkaji hal tersebut sebagaimana yang menjadi inti permasalahan penelitian, dilakukan kajian kepustakaan, yaitu dengan mempelajari buku-buku, dokumen-dokumen, putusan peradilan, serta bahan-bahan dari berbagai sumber lainnya. Bahan-bahan yang telah didapatkan dianalisis dan ditulis dengan pendekatan deduktif.

\section{PEMBAHASAN}

\section{Penormaan Syariat Islam di Aceh}

Untuk memahami penerapan syariat islam di Aceh diperlukan adanya informasi yang harus dipahami cukup oleh banyak pihak tentang hal itu. Informasi tentang syariat Islam di Aceh harus dipahami dari aspek philosofis, yuridis dan sosiologis.

Undang-Undang Dasar Negara Republik Indonesia Tahun 1945 menegaskan bahwa Negara Indonesia ialah Negara Kesatuan yang berbentuk republik. Sebagai negara kesatuan, maka Indonesia dibagi atas daerah provinsi, dan daerah provinsi itu dibagi atas kabupaten dan kota, yang tiap-tiap provinsi, kabupaten, dan kota diakui dan dihormati satuan-satuan pemerintahan daerah yang bersifat khusus atau bersifat istimewa.

Sebagai penjabaran kehendakan konstitusional tersebut, maka di Indonesia telah dibentuk provinsi sebanyak 34 provinsi, dengan 3 jenis status yaitu (1) daerah otonomi dengan status istimewa, (2) daerah otonomi dengan status khusus, dan (3) provinsi berstatus sebagai otonomi luas.

Berdasarkan status tersebut, dari keseluruhan daerah provinsi tersebut yang berstatus daerah istimewa adalah Provinsi Daerah Khusus Ibu Kota Jakarta dan Daerah Istimewa Yogyakarta. Daerah provinsi dengan status sebagai daerah khusus adalah Provinsi Papua, Provinsi Papua Barat dan Provinsi Aceh, sedangkan 29 daerah provinsi lain adalah berstatus sebagai provinsi dengan otonomi luas.

Kekhususan Provinsi berdasarkan undang-undang adalah untuk melaksanakan syariat Islam di Aceh. Berdasarkan undang-undang, maka kepada Provinsi Aceh dapat melaksanakan syariat Islam. Kekhususan ini didasarkan pada sejarah dan kondisi faktual bahwa penduduk Aceh hampir mencapai $100 \%$ beragama Islam.

Pelaksanaan syariat Islam di Aceh menurut sejarah ditandai dengan masuknya ajaran agama Islam yang pertama di wilayah Indonesia melalui wilayah Aceh, yaitu wilayah Kerajaan Samudera Pasai (Zainuddin Ali, 2008:79) yang terletak di Kabupaten Aceh Utara sekarang. 
Melalui perdagangan, pengaruh dakwah Islam dengan cepat telah menyebar hingga ke berbagai wilayah nusantara yang kemudian telah menyebabkan beberapa kerajaan Islam berdiri menyusul berdirinya Kerajaan Samudera Pasai di Aceh. Tidak jauh dari Aceh berdiri Kesultanan Malaka, lalu di pulau Jawa berdiri Kesultanan Demak, Mataram dan Cirebon, kemudian di Sulawesi dan Maluku berdiri Kerajaan Gowa dan Kesultanan Ternate serta Tidore.

Secara yuridis, pelaksanaan syariat Islam di Aceh setelah merdeka mulai diakui sejak adanya perdamaian antara Darul Islam di Aceh dengan pemerintah Indonesia yang diwakili oleh Mr. Hardi yang menjabat sebagai Wakil Perdana Menteri I.

Berdasarkan perdamain itu, dicapai kata sepakat dengan memberikan Aceh sebagai sebuah provinsi dengan keistimewaan. Keistimewaan itu meliputi pemberian hakhak otonomi yang luas dalam tiga bidang, yaitu bidang agama, pendidikan dan adat budaya. Sebagai penjabarannya, lama tahun berselang lahirlah Undang-Undang Nomor 44 Tahun 1999 tentang Penyelenggaraan Keistimewaan Propinsi Daerah Istimewa Aceh.

Landasan yang kuat terhadap terhadap pelaksanaan syariat Islam di Aceh juga diberi landasan hukum yang lain, Undang-Undang Nomor 18 Tahun 2001 Tentang Otonomi Khusus Bagi Provinsi Daerah Istimewa Aceh Sebagai Provinsi Nanggroe Aceh Darussalamotonomi Khusus Bagi Provinsi Daerah Istimewa Aceh Sebagai Provinsi Nanggroe Aceh Darussalam, yang kemudian digantikan dengan Undang-Undang Nomor 11 Tahun 2006 tentang Pemerintahan Aceh.

Berdasarkan Undang-Undang ini, Pemerintah Republik Indonesia secara tegas memberikan kewenangan kepada masyarakat Aceh untuk menerapkan syariat Islam di Aceh. Dalam ketentuan Pasal 125 undang-undang ini ditegaskan bahwa Syari'at Islam yang dilaksanakan di Aceh meliputi aqidah, syar'iyah dan akhlak.

Berdasarkan ketentuan tersebut, nampaklah bahwa syariat Islam yang diberikan kewenangan kepada Pemerintahan Aceh tidak meliputi semua bidang, melainkan hanya pada tiga bidang saja, dan dari ketiga bidang ini tercakup bagian-bagiannya, yaitu ibadah, ahwal alsyakhshiyah (hukum keluarga), muamalah (hukum perdata), jinayah (hukum pidana), qadha' (peradilan), tarbiyah (pendidikan), dakwah, syiar, dan pembelaan Islam.

Secara yuridis formal, undang-undang tersebut memerintahkan pemberlakuan syariat Islam di Aceh pada semua bidang tersebut harus diberikan payung hukum, yaitu dengan Qanun Aceh. Kenyataannya, belum semua bidang hukum yang telah diatur dengan Qanun Aceh, melainkan baru aturan yang berkenaan bidang jinayah saja.

Bidang jinayah ini diberi landasan yuridis dengan Qanun Provinsi Nanggroe Aceh Darussalam Nomor 10 Tahun 2002 tentang Peradilan Islam, Qanun Provinsi Nanggroe Aceh Darussalam Nomor 11 Tahun 2002 tentang Pelaksanaan Syariat Islam Bidang Aqidah, Ibadah dan Syiar Islam. Satu tahun kemudian, lahir lagi Qanun Provinsi Nanggroe Aceh Darussalam Nomor 12 Tahun 2003 tentang Khamar (Minuman Keras), Qanun Provinsi Nanggroe Aceh Darussalam Nomor 13 Tahun 2003 tentang Maisir (Judi), dan Qanun Provinsi Nanggroe Aceh Darussalam Nomor 14 Tahun 2003 tentang Khalwat (Mesum). Qanun-qanun tersebut kemudian diganti dengan dibentuknya Qanun Aceh Nomor 6 Tahun 2014 tentang Jinayah.

\section{Tahapan dan Metode Komunikasi Syariat Islam Kepada Masyarakat}

Pemberlakuan syariat Islam memerlukan komunikasi secara komprehensive agar semua orang mengetahui dengan benar syariat Islam di Aceh. Pengetahuan tentang syariat Islam di Aceh tidak hanya perlu diketahui oleh masyarakat di Aceh melainkan pula para pejabat publik di negeri Republik Indonesia.

Oleh karena itu, pada masa pembentukan Undang-Undang Nomor 11 Tahun 2006 Tentang Pemerintahan Aceh, di Aceh telah dilakukan berbagai penjaringan pendapat dari 
berbagai komponen masyakat di Aceh. Hal tersebut dilakukan oleh tim penyusun pra undang-undang pemerintahan Aceh. Tim itu bekerja Pasca Tsunami dan Memorandum of Understanding antara Pemerintah Republik Indonesia dengan Gerakan Aceh Merdeka di Helshinky. Tim ini terdiri dari, antara lain dari unsuru Universitas Syiah Kuala dan Institut Agama Islam Negeri Ar-Raniry.

Penjaringan informasi dan pendapat dari tim pembentuk perundang-undangan kepada masyarakat atau stake holder, dalam bahasa hukum disebut dengan konsultasi public atau disebut pula dengan public hearing. Komunikasi yang seperti ini telah terjadi jauh sebelum adanya draft rancangan perundang-undangan, karena undang-undang menghendaki pembentukan perundang-undangan harus diawali dengan adanya naskah akademik.

Naskah akademik menurut Undang-Undang Nomor 12 Tahun 2011 Tentang Pembentukan Perundang-undangan adalah naskah hasil penelitian atau pengkajian hukum dan hasil penelitian lainnya terhadap suatu masalah tertentu yang dapat dipertanggungjawabkan secara ilmiah mengenai pengaturan masalah tersebut dalam suatu Rancangan Undang-Undang, Rancangan Peraturan Daerah Provinsi, atau Rancangan Peraturan Daerah Kabupaten/Kota sebagai solusi terhadap permasalahan dan kebutuhan hukum masyarakat.

Sebagai suatu penelitian, maka pembentukan naskah akademik harus mengikuti metode penelitian ilmiah. Dalam metode penelitian ilmiah, dituntut para peneliti untuk menampilkan hasil penelitiannya secara berdasarkan data-data yang dikumpulkan. Data itu dikumpulkan dengan melakukan penelitian di kehidupan masyarakat (penelitian lapangan), baik melalui wawancara, kuestioner ataupun melalui focus group discusion (FGD. Pendekatan yang diambil dalam pengumpulan data dari masyarakat, merupakan bagian dari penyampaian aspirasi dari masyarakat sebagai realitas sosial (Deddy Mulyana, 2011: 191). Melalui pendekatan ini maka mulai terjalin komunikasi antara stake holder dengan pihakpihak yang memiliki kewenangan untuk membuat keputusan.

Adanya penjaringan aspirasi seperti ini merupakan kewajiban dari dicantumkannya asas keterbukaan dalam pembentukan undang-undang. Penjelasan Undang-Undang Nomor 12 Tahun 2011, menyebutkan asas keterbukaan adalah asas yang menegaskan bahwa dalam Pembentukan Peraturan Perundang-undangan mulai dari perencanaan, penyusunan, pembahasan, pengesahan atau penetapan, dan pengundangan bersifat transparan dan terbuka.

Uundang-undang tersebut, menghendaki adanya komunikasi dua arah (lihat: Hafied Cangara, 1998:45) dalam pembentukan undang-undang, antara stake holder dan perancang undang-undang. Undang-undang mengharapkan sema lapisan masyarakat mempunyai kesempatan yang seluas-luasnya untuk memberikan masukan dalam Pembentukan Peraturan Perundang-undangan.

Berdasarkan naskah akademik yang disusun, maka naskah akademik wajib diseminarkan. Melalui seminar ini diharapkan terjadinya komunikasi kembali antara perancang dengan stake holder. Stake holder memiliki kesempatan yang sebesar-besarnya untuk memberikan justifikasi terhadap naskah akademiik yang telah tersusun.

Naskah akademik yang telah tersusun yang memenuhi landasan filosofis, yuridis dan sosiologis akan memberikan kemudahan bagi perancang perundang-undangan dan anggota masyarakat lainnya dalam meninjau pembentukan norma dari perundang-undangan. Pada tingkat perancangan norma dari perundang-undangan, maka sebaiknya perundangundangan harus dilakukan diskusi publik atau kadang kala disebut dengan uji publik. Uji publik ini mengunakan metode seminar atau sarasehan. Kegiatan ini pada dasarnya dilakukan untuk menguji kesesuaian antara norma-norma yang telah disusun dengan kebutuhan hukum dari masyarakat. 
Untuk efektifnya komunikasi ini, maka biasanya forum komunikasi ini dibentuk dalam kelompok-kelompok kecil dan dilakukan secara maraton pada banyak tempat sesuai dengan kebutuhan. Semakin banyak orang yang diikut sertakan dalam uji publiik, maka diharapkan kesempurnaan dari naskah rancangan semakin baik pula.

Untuk pembentukan Qanun Aceh tentang Jinayah, maka stake holder yang terlibat dalam penjaringan pendapat, selain orang-perorangan atau organisasi maka terdapat kewajiban yuridis untuk melibatkan organisasi keulamaan di Aceh yang disebut dengan Majelis Permusyawaratan ulama. Hal ini karena menurut Undang-Undang Nomor 11 Tahun 2006 Tentang Pemerintahan Aceh, organisasi ini berwenang untuk memberikan pertimbangan kepada Gubernur dan Dewan Perwakilan Rakyat Aceh dalam mengambil kebijakan di bidang keagamaan.

Selain secara komunikasi konvensional, maka komunikasi antara stake holder dengan perancang undang-undang dapat pula dilakukan melalui media massa, dan secara eletronik. Melalui media masa dan elektronik, maka masyarakat dapat menyampaikan secara tertulis terhadap naskah yang telah dipublikasi tersebut. Di Provinsi Aceh, sesuai dengan Qanun Aceh tentang Pembentukan Qanun, ditegaskan bahwa sebelum dilakukan pembahasan bersama atas rancangan qanun di Dewan Perwakilan Rakyat Aceh, maka rancangan qanun tersebut harus terlebih dahulu di publikasi di media masa dan media elektronik.

Demikin pula pada tahapan pembahasan rancangan qanun, konsulatasi publik masih harus dilakukan. Pada tahapan ini, maka konsultasi publik menjadi kewajiban dari Dewan Perwakilan Rakyat Aceh. Menurut tata tertib Dewan Perwakilan Rakyat Aceh, konsulatasi publik disebut dengan Rapat Dengar Pendapat Umum (RDPU).

Melalui RDPU, maka dewan berupaya untuk berkomunikasi secara langsung dengan stake holder terhadap norma-norma yang telah tersusun. Masyarakat diharapkan dapat mengkritisi secara tajam atas rancangan norma yang telah ada. RDPU ini juga oleh dewan dilakukan secara estafet pada beberapa daerah di Aceh.

Komunikasi pada tahapan ini dan tahapan sebelumnya bersifat dua arah, hal ini karena pada tahapan ini terjadi adanya dialog dan diskusi terhadap norma-norma yang disusun, yang sekaligus dapat mencari pemahaman bersama. Hal tersebut sungguh berbeda dengan tahapan setelah suatu rancangan qanun itu disahkan. Pada tahapan ini, masyarakat tidak lagi diminta pendapat, melainkan masyarakat disampaikan informasi terhadap normanorma yang telah disahkan.

Komunikasi seperti ini bersifat penjelasan terdapat norma yang telah terbentuk, bukan lagi meminta pendapat. Oleh karena itu komunikasi seperti ini disebut dengan sosialisasi (Onong Uehjana Effendy, 1984: 31). Pada dasarnya sosialisasi merupakan kegiatan penyebar luasan informasi terhadap norma-norma yang sudah dibentuk.

Kegiatan mengkomunikasikan norma-norma sangatlah penting, karena adanya informasi yang cukup yang diterima oleh masyarakat akan menciptakan efektivitas dari penerapan hukum itu. Ruang bagi masyarakat untuk mendapatkan informasi melalui penempatan dalam lembaran daerah tidaklah cukup. Faktanya tidak semua orang dapat melihat lembaran daerah itu, apalagi masyarakat pedesaan yang tidak memiliki akses informasi, sehingga norma-norma itu tidak dapat terkomunikasi dengan baik. Oleh karena itu, hanya mengandalkan pada keberadaan teori fiksi saja, yang menegaskan bahwa sejak perundang-undangan ditempatkan dalam lembaran daerah semua orang dianggap sudah tahu belumlah cukup.

Pentingnya dikomunikasikan kepada masyarakat terhadap norma-norma dalam perundang-undangan itu, dalam Qanun Aceh tentang Jinayah dapat dilihat sebagai contoh. Dalam Qanun Aceh itu pemberlakuan qanun itu kepada masyarakat tidak serta merta sejak diundangkan qanun tersebut. 
Pembentuk Qanun Aceh itu, pada saat pembahasan di Dewan Perwakilan Rakyat Aceh sudah melihat tentang perlunya dikomunikasikan norma-norma qanun itu ke masyarakat. oleh karena itu qanun itu baru diberlakukan setahun setelah diundangkan. Adanya tenggang waktu antara pengundangan dan pemberlakuan adalah untuk memberikan ruang waktu yang memadai bagi pihak Pemerintah Aceh, Kejaksaan, Kepolisian dan Mahkamah Syar'iah dalam mengkomunikasikan norma-norma itu ke masyarakat.

Selain itu, waktu setahun itu juga penting bagi Pemerintah Aceh, Kejaksaan, Kepolisian dan Mahkamah Syar'iah untuk membekali diri dalam rangka penegakan hukumnya. Menurut teori, hukum itu akan berjalan dengan baik di tengah-tengah masyarakat, tidak hanya pada substansi hukum yang baik, tetapi juga ditentukan oleh sarana dan parasarana dan sumber daya manusia yang menegakkan hukum itu.

\section{PENUTUP}

Terkomunikasi dengan baik suatu perundang-undangan kepada stake holder akan sangat menentukan suatu perundang-undangan diterima dan berjalan dengan baik di tengah-tengah masyarakat. Untuk itu, setiap pembentukan undang-undang sejak awal sudah harus berjalan komunikasi dua arah antara pembentuk undang-undang dengan stake holder. Komunikasi itu dalam pembentukan dan penerapan Qanun Aceh tentang Jinayah sudah diupayakan untuk dilakakukan, berdasarkan model-model dari komunikasi yang bersifat massa.

\section{DAFTAR PUSTAKA}

Dedy Mulyana, Ilmu Komunikasi, Suatu Pengantar, Remaja Rosda Karya, Bandung, 2011. Hafied Cangara, Pengantar Ilmu Komunikasi, Rajawali Pers, Jakarta, 1998.

Onong Uehjana Effendy, Komunikasi Teori dan Praktek, Remaja Rosdakarya, Bandung, 1984.

Soeroso, R., Pengantar Ilmu Hukum, Sinar Grafika, Jakarta, 2004.

Zainuddin Ali, Hukum Islam, Pengantar Ilmu Hukum Islam di Indonesia, Sinar Grafika, Jakarta, 2008. 